\title{
Properties and Classification of Soils Developed Under Shalla Mango Orchard in Malikawa Village, Kware Local Government Area, Sokoto State, Nigeria
}

\author{
Hayatu $\mathrm{NG}^{1}$, Nabayi $\mathrm{A}^{2}$, Sharu $\mathrm{MB}^{3 *}$, Buji $\mathrm{IB}^{4}$, MahmudAT ${ }^{2}$, Abdulwahab $\mathrm{MO}^{1}$, Girei $\mathrm{AH}^{2}$, Yusif
} $\mathrm{SA}^{2}$, Saadu I ${ }^{5}$, Abubakar SD ${ }^{5}$, Dangaladima $\mathrm{W}^{3}$, Sani. $\mathrm{I}^{6}$ and Samim $\mathrm{S}^{7}$

${ }^{\mathrm{T}}$ Department of Soil Science and Agricultural Engineering, Usmanu Danfodiyo University, Sokoto, Nigeria PMB 2346 Sokoto State

${ }^{2}$ Department of Soil Science, Federal University Dutse, Jigawa state Nigeria Ibrahim Aliyu bye-pass PMB 7156 Dutse, Jigawa State

${ }^{3}$ Department of Agricultural Science, Shehu Shagari College of Education, Sokoto, Sokoto State

${ }^{4}$ Department of Soil Science, Faculty of Agriculture, University of Maiduguri P.M.B. 1069 Maiduguri, Borno State

${ }^{5}$ Department of Geography, Faculty of Social Science, Usmanu Danfodiyo University, Sokoto, Nigeria PMB 2346

Sokoto State

${ }^{6}$ Department of Chemistry, Zamfara State College of Agriculture, Maru

${ }^{7}$ Department of Agricultural Economics \& Extension, Takhar University, Afghanistan

\section{*Corresponding Author}

Sharu MB

\section{Article History}

Received: 21.08.2020

Accepted: 29.08.2020

Published: 06.09.2020

\begin{abstract}
A reconnaissance soil survey and image analysis of Kware town Fringes was conducted to determine the effect of orchard cultivation on some soil properties. Two profile pits were dug and described in line with FAO guidelines for soil description. The data obtained were subjected to both descriptive and inferential statistics. Soils for orchard cultivation were clay loam in texture. The soil units were rated low in OC $\left(1.20-10.80 \mathrm{~g} \mathrm{~kg}^{-1}\right), \mathrm{EC}\left(0.01 \mathrm{dSm}^{-1}\right)$ and bulk density $\left(1.0-1.6 \mathrm{gcm}^{-3}\right)$. Similarly, all the soil units were also rated high in exchangeable $\mathrm{Na}(1.47-1.54 \mathrm{cmol}$ $\mathrm{kg}^{-1}$ ) and PBS (95.54-98.74\%). The soil units were classified using USDA and WRB systems. Soils of the study site were high in CEC $\left(15.55 \mathrm{cmol} \mathrm{kg}^{-1}\right)$ and OC $\left(6.70 \mathrm{~g} \mathrm{~kg}^{-1}\right)$ as such incorporation of organic residues and reduced tillage was recommended to improve their fertility status. Soils of orchard cultivation were slightly alkaline (7.29), as such the soils are suitable for mango cultivation as it falls within optimum range.
\end{abstract}

Keywords: Orchard, cultivation, physical and chemical properties.

\section{INTRODUCTION}

Soil is a complex mixture of mineral nutrients, organic matter, water, air, and living organisms determined by various environmental factors such as climate, parent materials, relief, microorganisms, and time factors [1]. As the interface between the atmosphere, biosphere, and lithosphere, soil undergoes an intense vertical exchange of materials resulting in steep chemical and physical gradients from the surface to bedrock [2].

Agriculture is a major use of land, and the share of land used for agriculture has been slowly increasing across most of the world's regions over the past few decades as population increases [3]. Increasing population growth will continue to exert very high pressure on land resources. And for this reason, over the decades in both agriculturally advanced and small-scale crop production, nutrient replenishment through fertilizers and manures will continue to remain far below crop removal, thus causing the depletion of nutrient reserves [4]. Furthermore, these problems will continue to aggravate due to unsustainable land resource management strategies coupled with population pressure [5-7].

Copyright @ 2020: This is an open-access article distributed under the terms of the Creative Commons Attribution license which permits unrestricted use, distribution, and reproduction in any medium for non commercial use (NonCommercial, or CC-BY-NC) provided the original author and source are credited. 
Nigeria has an estimated land area of $904,000 \mathrm{~km}^{2}$ with a population of over 120 million in which about $65 \%$ of the land area is under various forms of food (crop and animal) production and forest plantation [8]. The continuous conversion of tropical cropland to grassland or forest causes variation in soil parameters [9] as well as the overall natural environment [10]. Some soil properties such as nutrient contents ( $\mathrm{N}, \mathrm{P}, \mathrm{K}, \mathrm{Ca}, \mathrm{Mg}, \mathrm{S}$, etc.), pH, organic matter, CEC, structure etc. differs with changes in land use [11]. Again, the physico-chemical characteristic entails the potential status of nutrients distribution in soils of different land uses $[12,13]$. Recent studies are validating the justification that land-use changes can have effects on soil fertility [14]. The results of physical and chemical properties provide information about the supplying capacity of soil mineral nutrients [15].

Land use changes and managements practices brings about changes in soil physical, chemical, morphological chemical and biological properties the effect to which is well reflected in the soil productivity [16]. Knowledge on how soils respond to management practices overtime is the key to maintaining soil quality. Nowadays, the increase in awareness that soil is an important component of the earth biosphere which not only functions in the production of food and fiber, but also in the maintenance of local, regional and worldwide environmental quality has trigger the interest in evaluating the quality of our soil resources [17]. Furthermore, feeding of the ever-increasing population is an important challenge looking at the degradation rate of our soils. For instance, in Sub-Saharan African countries, soil fertility depletion is the fundamental biophysical cause for declining per capita food production [18]. Land use has affected significantly the basic processes of erosion, soil structure and aggregate stability, nutrient cycling, leaching, carbon sequestration, and other similar physical and biochemical processes [19]. This challenge will continue as population increases and degradation of soil resources is aggravated.

The need to generate adequate knowledge of soil is by the exploration of soil properties at different depths, which would provide relevant information on patterns of nutrients accumulation and redistribution of both surface and deep layers of the soil for proper utilization of land resources [20]. The study and understanding of the effect of orchard cultivation on the soil will be useful for the development of a soil management plan for the efficient utilization of limited land resources. Hence, the objective of the research is to investigate the effect of physical and chemical characteristics of the soils and agricultural potentials and constraints for sustainable yield as well as crop production.

\section{Materials ANd MethodS \\ Description of the Study Area}

This research was conducted at Malikawa village, Kware Local Government area, Sokoto state. Malikawa is located between latitude $13^{0} 13$ ' $22.27^{\prime \prime}$ to $13^{0} 13^{`} 21.39^{\prime \prime} \mathrm{N}$ and longitude $5^{0} 16^{\prime} 34.74^{\prime \prime}$ to $5^{0} 16^{\prime} 35.83^{\prime \prime}$ E. The climate of the area is characterized by Tropical climate with an average rainfall of $565 \mathrm{~mm} /$ year [21]. The minimum temperature is $27{ }^{0} \mathrm{C}$ while the maximum temperature is $40{ }^{\circ} \mathrm{C}$ [21]. The relative humidity during dry season is about $15-20 \%$ and reaches up to $70-75 \%$ during the rainy season. Agriculture is one of the dominant activities engaged by the people of Malikawa villages. The dominant underlying geology of the study area is Cretaceous and Tertiary sediments [22]. The vegetation is largely that of the Sudan zone, which contains savannah woodland on the better soils and tree and shrub savannah on the poorer ones. The major land use types in the study were arable crop production both at upland and lowland areas and non-agricultural uses such as residential, quarry and mining, roads construction etc.

\section{Field Work}

Two (2) farmers plot located at Malikawa village were purposely selected for the study. The farms were cultivated for over 20 years with Millet-Cowpea-Sorghum intercrop under the mango orchard. The general site description such as climate, vegetation, land use, slope gradient, drainage type and condition, type and degree of erosion and depth to ground water table were recorded. Two profile pits $(2 \times 1.5 \times 2 \mathrm{~m})$ were dug and described morphologically following FAO [23] guidelines. For each profile, depth, colour, texture, structure, consistence, roots, pores, inclusions, as well as boundary characteristics were recorded. Garmin eTrex 10 global positioning system (GPS) device was used in recording the coordinates.

\section{Sample Collection and Preparation}

Soil samples were collected from each genetic horizon of the two profile pits dug. Similarly, undisturbed soil samples for bulk density determination were taken using core samplers of known volume, whereas disturbed samples for other physical and chemical parameters determination were taken in nylons, labelled accordingly and transported to the laboratory. The samples for bulk density determination were oven dried at $105{ }^{\circ} \mathrm{C}$ for 48 hours. Disturbed soil samples on the other hand, were air-dried for 24 hours, crushed gently using pestle and mortar and pass through $2 \mathrm{~mm}$ sieve. Particles $<2 \mathrm{~mm}$ were used in the laboratory analyses.

\section{Laboratory Analyses}

Soil samples were subjected to series of analyses; particle size analysis was determined following Bouyoucos Hydrometer [24] method, bulk density was by core sampler method as described by Blake and Hartge [25]. Particle 
density was determined by the use of Pycnometer bottle method [26]. Total porosity was calculated from particle and bulk density values using the following relationship:

$$
P=100\left(1-\frac{B d}{P d}\right)
$$

Where $\mathrm{P}$ is porosity, $\mathrm{Bd}$ is bulk density, $\mathrm{Pd}$ is particle density

Soil $\mathrm{pH}$ was determined both in water and $0.01 \mathrm{M} \mathrm{CaCl}_{2}$ with a glass electrode $\mathrm{pH}$ meter at 1:2.5 soil to liquid ratio [27]. Organic carbon was determined by wet oxidation method as described by Nelson and Sommers [28]. Total nitrogen $(\mathrm{N})$ was determined using the Micro-Kjeldahl digestion and distillation method [29]. Available phosphorus was extracted following Bray No. 1 method and determined using molybdenum blue method [30]. Cation exchange capacity (CEC) was determined by the neutral ammonium acetate saturation method buffered at $\mathrm{pH} 7$ [24]. Exchangeable bases $\left(\mathrm{Ca}, \mathrm{Mg}, \mathrm{K}\right.$ and $\mathrm{Na}$ ) were determined by extraction with neutral $1 N \mathrm{NH}_{4} \mathrm{OAC}$ saturation method. $\mathrm{Ca}$ and $\mathrm{Mg}$ were read using atomic absorption spectrophotometer (AAS), whereas $\mathrm{K}$ and $\mathrm{Na}$ were read using Flame Photometer [24]. Percentage base saturation (PBS) of the soils was calculated using the following relationship:

$$
\text { PBS }=\frac{\sum \text { (Exchangeable Bases) }}{\text { CEC }} \times 100
$$

Where; PBS is percent base saturation, and CEC is cation exchange capacity

\section{Data Analysis}

The data collected and generated were analyzed statistically for descriptive statistics such as means, ranges, and percentages and Pearson's (r) correlation analysis using SPSS statistical package version 20.

\section{RESUlTS AND DiSCUSSION}

\section{Description of the Soils of Orchard Lands}

Soils of the orchard plantation are mainly dominated by mango trees (Mangifera indica). The farmers cultivate the orchard with arable crops such as sorghum, millet, cowpea and groundnut in the rainy season. During the dry season, they also cultivate vegetable crops such as onions and okra by irrigation.

\section{Morphological properties of the soils of orchard lands}

The morphological properties of Pedons Orc P1 and P2 are presented in Table 1. Both pedons in the orchard land were shallow $(70 \mathrm{~cm})$ to moderately $(114 \mathrm{~cm})$ deep profiles. Pedon Orc-P1 had three generic soil horizons (Ap-Bw$\mathrm{AB}$ ), while Pedon Orc-P2 had four horizons (Ap-Bw1-AB-Bw2). The Pedons were similar in terms of horizonation and horizons thickness. The pedons had slight discernable variations in relation to surface and subsoil colour patterns. The colours varied from yellowish brown (10YR5/4) to dark yellowish brown (10YR4/6) dry in Pedon Orc P1 and P2 surface layers respectively (Table 1) depicting the influence of topography, location, weathering, parent material and organic matter content. The colour of the subsurface horizons ranged from reddish yellow (7.5YR6/6) to dark brown (10YR4/3) in the $\mathrm{Bw}$ and $\mathrm{AB}$ of Pedon Orc-P1 respectively to yellow (10YR 7/6) in the deepest subsurface horizon of Pedon Orc-P2 (i.e. Bw2).

The soils of orchard lands (Table 1) had similar soil texture. The surface horizons of Pedon Orc P1 and P2 were sandy loam in texture, whereas, the subsurface horizons were sand to sandy loam in texture. These types of soil texture (clay loam and/or sandy loam) according to Masabni and Strang [31] are better-suited for fruit trees than very sandy or heavy clay soils. Soil structure of the surface Pedons were sub-angular blocky, except for Bw2 of Pedon Orc-P2 which was single grain. The poor or weak soil structure observed could be attributed to the effect of cultivation, owing to the fact that, traces of arable crops (evident by stumps) cultivation was observed within the orchard. This further shows that, what the farmers are practicing is no longer a single land use, but rather, a multiple land use. Differences were also observed in terms of consistency, with majority of the horizons being hard when dry. This could also be attributed to the water content and type of mineral that make up the soils. For instance, Bw2 horizon is sandy in texture, single grain in structure and loose (dry) in consistence, depicting the presence of primary minerals (such as kaolinite, quartz etc).

Another striking feature of the soils as shown in Table 1 is the possession of shallow water-table corroborating the previous findings of Anonymous [32] who observed that water table is generally deeper beneath hills and shallower beneath valleys. The water-table of Pedon Orc-P1 is shallower (around $70 \mathrm{~cm}$ deep) than that of Pedon Orc-P2 (around $114 \mathrm{~cm}$ deep), indicating differences in elevation and position of the profiles as well as their relative closeness to the nearby water stream (also known as Shalla) that supplies the orchard with water all year round. This result has contradicted the findings of Masabni and Strang [31] who opined that, areas with high water-table are not well-suited for orchard plantation. 
Table-1: Morphological Properties of the Soils of Malikawa Series Pedons Orc P1 and P2

\begin{tabular}{|c|c|c|c|c|c|c|c|}
\hline Horizon & Depth (cm) & Colour & Texture ${ }^{1}$ & Structure $^{2}$ & Consistence $^{3}$ & Boundary $^{4}$ & Other Features 5 \\
\hline \multicolumn{8}{|c|}{ Malikawa Series- Pedon Orc P1 (Aquic Ustipsamments/Rubic Arenosols (Eutric) } \\
\hline Ap & $0-8$ & $10 \mathrm{YR} 5 / 4$ & SL & sab & $\mathrm{h}$ & gs & mfmlr, ffp, fmwc \\
\hline $\mathrm{Bw}$ & $8-12$ & $7.5 \mathrm{YR} 6 / 6$ & SL & sab & $\mathrm{h}$ & cs & mfmlr, ffp, \\
\hline $\mathrm{AB}$ & $12-70$ & $10 \mathrm{YR} 4 / 3$ & SL & sab & $\mathrm{h}$ & ds & fmlr, mfp \\
\hline- & $>70$ & Water table & & & & & \\
\hline \multicolumn{8}{|c|}{ Malikawa Series- Pedon Orc P2 (Aquic Ustipsamments/Rubic Arenosols (Eutric) } \\
\hline Ap & $0-10$ & $10 \mathrm{YR} 4 / 6$ & SL & sab & $\mathrm{h}$ & gw & fmr, mmp \\
\hline Bw1 & $10-41$ & 10YR5/8 & $\mathrm{S}$ & sab & $\mathrm{s}$ & $\mathrm{dw}$ & ffr, fmp \\
\hline $\mathrm{AB}$ & $41-63$ & $10 \mathrm{YR} 3 / 6$ & $\mathrm{~S}$ & sab & $\mathrm{s}$ & $\mathrm{dw}$ & flr \\
\hline Bw2 & $63-114$ & 10YR7/6 & $\mathrm{S}$ & $\mathrm{sg}$ & 1 & $\mathrm{dw}$ & fmr \\
\hline- & $>114$ & Water table & & & & & \\
\hline
\end{tabular}

${ }^{5} \mathrm{mfmlr}=$ many fine medium and large roots, $\mathrm{fmlr}=$ few medium and large roots, fmr= few medium roots, $\mathrm{ffr}=$ few fine roots, flr $=$ few large roots, $\mathrm{ffp}=$ few fine pores, $\mathrm{mfp}=$ medium fine pores, $\mathrm{mmp}=$ many medium pores, $\mathrm{fmwc}=$ few medium widely spaced cracks Physical properties of the soils of orchard plantation lands

The soils of orchard plantation land were generally sandy loam in texture in the surface horizons. The subsurface horizons of Pedons Orc P1 and P2 were sandy loam and sand in texture respectively. In the surface horizons of Pedons Orc P1 and P2, the sand contents ranged from 68.0 to $70.0 \%(69 \%)$ and was rated high. The silt and clay content of the soils ranged from 15.7 to $17.7 \%(16.7 \%)$ and 14.3 to $14.3 \%(14.3 \%)$ and were rated low respectively. For the underlying horizons, the sand, silt and clay contents varied from 68.0 to $89.6 \%(78.8 \%), 7.9$ to $17.7 \%(12.8 \%)$ and 2.5 to $14.3 \%(8.4 \%)$ respectively (Table 3$)$. In both pedons, the percent sand was observed to have increased with increasing depth, whereas the percent silt and clay were found to have decreased with increasing depth in an irregular pattern. The high silt and clay contents observed in the surface than the subsurface horizons could be attributed to seasonal fluxes of silt and clay (sedimentation process) via alluvial deposition. The high sand content observed could be attributed to the effect of cultivation and crop removal, because the farmers are not practicing sole orchard cultivation but rather a kind of Tungia system.

The bulk density values in the surface horizons of Pedons Orc P1 and P2 ranged from 1.0 to $1.3 \mathrm{gcm}^{-3}\left(1.2 \mathrm{gcm}^{-}\right.$ ${ }^{3}$ ) and was rated low. For the underlying horizons, bulk density values varied from 1.0 to $1.6 \mathrm{gcm}^{-3}\left(1.3 \mathrm{gcm}^{-3} \mathrm{mean}\right)$ and was also rated low (Table 2). the bulk density varied irregularly with depth in the subsurface horizons of both pedons Orc P1 and P2. Similar results were reported by Salazar [33] who worked on agroforestry combined with water harvesting in the central zone of Chile and obtained a lower bulk density value of $1.1 \mathrm{~g} \mathrm{~cm}^{-3}$. This low bulk density can be attributed to increased soil organic matter, root activity of perennial trees, and increased soil biological activity by soil macrofauna $[34,35,33]$.

In the surface horizons of Pedons Orc P1 and P2, the total porosity varied from 47 to $65 \%$ (56\%) and was rated high. For underlying horizons, total porosity ranged from 37 to $71 \%(54 \%)$ and was also rated high. The total porosity of the soils varied irregularly with increasing soil depth (Table 2), which could be attributed to the bulk density of the soils. This result indicated an inverse relationship between bulk density and porosity. The bulk density had negatively but significantly correlated with total porosity $(\mathrm{r}=-0.988, \mathrm{p}<0.01)$ (Table 4).

Table-2: Physical Properties of the Soils of Malikawa Series Pedons Orc P1 and P2

\begin{tabular}{|c|c|c|c|c|c|c|c|c|}
\hline \multirow[t]{2}{*}{ Horizon } & \multirow[t]{2}{*}{ Depth (cm) } & \multicolumn{3}{|c|}{ Particle Size Distribution (\%) } & \multirow[t]{2}{*}{ Textural Class } & \multirow[t]{2}{*}{ Bulk Density } & \multirow{2}{*}{$\begin{array}{l}\text { Particle Density } \\
\mathrm{cm}^{-3}\end{array}$} & \multirow{2}{*}{$\begin{array}{c}\text { Porosity } \\
(\%)\end{array}$} \\
\hline & & Sand & Silt & Clay & & & & \\
\hline \multicolumn{9}{|c|}{ Malikawa Series- Pedon Orc P1 (Aquic Ustipsamments/Rubic Arenosols (Eutric) } \\
\hline Ap & $0-8$ & 68.0 & 17.7 & 14.3 & SL & 1.0 & 2.5 & 65 \\
\hline $\mathrm{Bw}$ & $8-12$ & 73.9 & 13.7 & 12.4 & SL & 1.0 & 2.5 & 71 \\
\hline $\mathrm{AB}$ & $12-70$ & 68.0 & 17.7 & 14.3 & SL & 1.4 & 2.5 & 44 \\
\hline- & $>70$ & \multicolumn{7}{|c|}{ Water table } \\
\hline \multicolumn{9}{|c|}{ Malikawa Series- Pedon Orc P2 (Aquic Ustipsamments/Rubic Arenosols (Eutric) } \\
\hline Ap & $0-10$ & 70.0 & 15.7 & 14.3 & SL & 1.3 & 2.5 & 47 \\
\hline Bw1 & $10-41$ & 87.6 & 9.9 & 2.5 & $\mathrm{~S}$ & 1.1 & 2.7 & 58 \\
\hline $\mathrm{AB}$ & $41-63$ & 87.6 & 9.9 & 2.5 & $\mathrm{~S}$ & 1.4 & 2.6 & 46 \\
\hline Bw2 & $63-114$ & 89.6 & 7.9 & 2.5 & S & 1.6 & 2.6 & 37 \\
\hline- & $>114$ & \multicolumn{7}{|c|}{ Water table } \\
\hline \multicolumn{2}{|c|}{ Mean } & 77.5 & 13.2 & 8.96 & SL & 1.3 & 2.56 & 49 \\
\hline \multicolumn{2}{|c|}{ SE } & 2.51 & 1.29 & 2.05 & - & 0.07 & 0.04 & 2.89 \\
\hline
\end{tabular}

$\mathrm{SE}=$ standard error, $\mathrm{SL}=$ sandy loam, $\mathrm{S}=$ sand 


\section{Chemical properties of the soils of orchard plantation lands}

The $\mathrm{pH}$ values in the surface horizons of Pedons Orc P1 and P2 ranged from 7.23 to 7.34 (7.29) and was rated slightly alkaline. For the underlying horizons, $\mathrm{pH}$ values varied from 6.65 to 7.99 (7.32) and was also rated slightly alkaline (Table 3). The $\mathrm{pH}$ values appeared similar between the Pedons Orc P1 and P2, and did not show much variability with depth. $\mathrm{pH}$ values of 6.5 to 8.0 are indications of high base saturation in soils [36]. According to Bally [37] mangoes are tolerant of a range of soils from alkaline, calcareous soils to heavy clay soils. The optimum $\mathrm{pH}$ range is 5.5 to 7.5 , but the tree will grow outside this range, with low $\mathrm{pH}$ (acid) being the most deleterious to growth. This shows that the $\mathrm{pH}$ (Table 3 ) of the soils is suitable for mango cultivation as it falls within optimum range.

The organic carbon content of the soils is generally low and ranged in the surface horizons of Pedons Orc P1 and $\mathrm{P} 2$ from 10.80 to $2.60 \mathrm{~g} \mathrm{~kg}^{-1}\left(6.70 \mathrm{~g} \mathrm{~kg}^{-1}\right)$. For the subsurface horizons, organic carbon content varied from 1.20 to $7.00 \mathrm{~g} \mathrm{~kg}^{-1}\left(4.10 \mathrm{~g} \mathrm{~kg}^{-1}\right)$ (Table 3). The lower levels of organic carbon in these soils could be attributed to low soil organic matter content. Correlation analysis showed significant negative relationship of organic carbon $(r=-0.828$, $\mathrm{p}<0.05$ ) with sand (Table 4).

The total nitrogen content in the surface horizons of Pedons Orc P1 and P2 ranged from 0.94 to $0.99 \mathrm{~g} \mathrm{~kg}^{-1}(0.97$ $\left.\mathrm{g} \mathrm{kg}^{-1}\right)$ and was rated high. For the subsurface horizons, total nitrogen varied from 0.35 to $2.11 \mathrm{~g} \mathrm{~kg}^{-1}\left(1.23 \mathrm{~g} \mathrm{~kg}^{-1}\right)$ and was also rated high (Table 3). The result is contrary to the findings of Akinola [38] and Skujins [31] who reported that most of the Nigerian soils to be low in nitrogen. The high nitrogen (Table 3) may be due to low leaching and volatilization of nitrogen as influenced by the tree canopy cover and to nitrogen supplied by the symbiotic bacteria (rhizobia) of the leguminous species cultivated alongside the orchard trees. In this study, positive but significant relationship of total nitrogen $(\mathrm{r}=0.686, \mathrm{p}<0.05)$ with $\mathrm{pH}$ was observed (Table 4).

The available phosphorus content in the surface horizons of Pedons Orc P1 and P2 ranged from 33.19 to 34.31 $\mathrm{mg} \mathrm{kg}^{-1}\left(33.75 \mathrm{mg} \mathrm{kg}^{-1}\right)$ and was rated high. For the underlying horizons, available phosphorus content varied from 10.94 to $44.88 \mathrm{mg} \mathrm{kg}^{-1}$ (27.91 mg kg $\mathrm{m}^{-1}$ ) and was also rated high (Table 3). The high phosphorus values may be due to appreciable quantity of clay content (Table 2), high cation exchange capacity values and slightly alkaline pH (Table 3) of the soils. This result is in line with that of Murthy [40] and Bopathi and Sharma [41-43] who reported red sandy soils of India to be low in phosphorus due to low cation exchange capacity values, clay content and soil reaction. Output of correlation matrix showed insignificant but positive relationship of available phosphorus with clay $(r=0.441, p>0.05)$ and cation exchange capacity $(\mathrm{r}=0.347, \mathrm{p}>0.05)$. It also indicated negative but insignificant relationship between available phosphorus and $\mathrm{pH}(\mathrm{r}=-0.195, \mathrm{p}>0.05)$.

The cation exchange capacity in the surface horizons of Pedons Orc P1 and P2 varied from 12.70 to $18.40 \mathrm{cmol}$ $\mathrm{kg}^{-1}\left(15.55 \mathrm{cmol} \mathrm{kg}^{-1}\right)$. For the underlying horizons, cation exchange capacity values ranged from 7.40 to $16.90 \mathrm{cmol} \mathrm{kg}^{-1}$ $\left(12.15 \mathrm{cmol} \mathrm{kg}^{-1}\right)$ (Table 3). The percent base saturation of the soils was generally high (Table 3), ranging from 98.04 to 98.74\% (98.39\%) in the surface horizons of Pedons Orc P1 and P2. For the subsurface horizons, percent base saturation varied from 95.54 to $98.82 \%$ (97.18\%). The cation exchange capacity and percent base saturation of the soils were both high (Table 3). From the result it could be observed that, there is positive relationship between cation exchange capacity and percent base saturation such that the higher the cations exchange capacity, the higher percent base saturation. Output of correlation matrix showed positive insignificant relationship $(r=0.864, p>0.05)$ between cation exchange capacity and percent base saturation. The high cation exchange capacity and percent base saturation values could be attributed to clay type and content, neutral soil reaction and organic matter content of the soils. Similarly, positive insignificant relationship of clay with cation exchange capacity $(r=0.927, \mathrm{Pp} 0.05)$ and percent base saturation $(r=0.899, \mathrm{p}>0.05)$ was observed (Table 4).

The calcium, magnesium, potassium and sodium contents in the surface horizons of Pedons Orc P1 and P2 ranged from 9.92 to $14.10 \mathrm{cmol} \mathrm{kg}{ }^{-1}\left(12.01 \mathrm{cmol} \mathrm{kg}^{-1}\right), 1.43$ to $1.82 \mathrm{cmol} \mathrm{kg}{ }^{-1}\left(1.63 \mathrm{cmol} \mathrm{kg}^{-1}\right), 0.10$ to $0.13 \mathrm{cmol} \mathrm{kg}^{-1}$ $\left(0.12 \mathrm{cmol} \mathrm{kg}^{-1}\right)$ and 0.70 to $2.38 \mathrm{cmol} \mathrm{kg}^{-1}\left(1.54 \mathrm{cmol} \mathrm{kg}^{-1}\right)$ respectively. For the underlying horizons, $\mathrm{Ca}, \mathrm{Mg}, \mathrm{K}$ and $\mathrm{Na}$ content varied from 5.44 to $13.20 \mathrm{cmol} \mathrm{kg}^{-1}\left(9.32 \mathrm{cmol} \mathrm{kg}^{-1}\right), 0.62$ to $1.65 \mathrm{cmol} \mathrm{kg}^{-1}\left(1.14 \mathrm{cmol} \mathrm{kg}^{-1}\right), 0.03$ to $0.12 \mathrm{cmol}$ $\mathrm{kg}^{-1}\left(0.08 \mathrm{cmol} \mathrm{kg}^{-1}\right)$ and 0.86 to $2.08 \mathrm{cmol} \mathrm{kg}{ }^{-1}\left(1.47 \mathrm{cmol} \mathrm{kg}^{-1}\right)$ respectively. The exchangeable bases distribution was in the order $\mathrm{Ca}>\mathrm{Na}>\mathrm{Mg}>\mathrm{K}$ (Table 3) contradicting previous findings that the dominant exchangeable bases in tropical soils are calcium and magnesium. Potassium appeared to be lowest and was attributed to effect of cultivation and crop removal. The high sodium values observed could be ascribed to the type and nature of the parent materials (the data not shown here).

\section{Soil classification}

The soils were classified according to the guidelines of the United State Department of Agriculture (USDA) Soil Taxonomy System (USDA-NRCS, 2010) and Correlated with World Reference Base (WRB) for Soil Resources (WRBIUSS Working Group, 2014) as follows: 


\section{USDA Classification}

These soil units (Orc-P1 and Orc-P2) were classified as Entisols at order level, as it does not fit into other soil orders. On the basis of an irregular decrease in organic carbon content with soil depth, these soil units were further classified as Fluvents at suborder level. Owing to Ustic moisture regime, the soil units were also classified as Ustifluvents at great-group level. At subgroup level they were classified as Aquic Ustifluvents, due to Aquic moisture characteristics.

\section{WRB Classification}

These soil units were classified at RSG of WRB system as Arenosols been predominantly sandy loam in texture. The soil units were further classified at soil unit level as Rubic Arenosols, because they possess within $100 \mathrm{~cm}$ of the soil surface a sub-surface layer $>30 \mathrm{~cm}$ thick with a Munsell Hue redder than 10YR. Furthermore, the soils have a base saturation $\left(\mathrm{NH}_{4} \mathrm{OAC}\right.$ buffered at $\mathrm{pH}$ 7) above 50 percent, the soil units were further classified as Rubic Arenosols (Eutric) at supplementary qualifier level.

\section{CONCLUSION}

The results indicate that the examined orchard soils were clay loam in texture. Bulk density values of the orchard soils were below the critical value of $1.6 \mathrm{gcm}^{-3}$ that causes poor aeration and hinders root penetration. The soils were generally of high fertility class, with the exception of exchangeable sodium and percent base saturation, which were observed to be high. The soil units studied were low in organic carbon content and were also slightly alkaline. The electrical conductivity of the soils across the orchard soils was generally low. The soils were also found to be high in total $\mathrm{N}$ while available $\mathrm{P}$ was rated medium across the soil profile.

Table-3: Chemical Properties of the Soils of Malikawa Series Pedons Orc P1 and P2

\begin{tabular}{|c|c|c|c|c|c|c|c|c|c|c|c|c|c|}
\hline \multirow{2}{*}{ Horizon } & \multirow{2}{*}{$\begin{array}{c}\text { Depth } \\
\text { (cm) }\end{array}$} & \multicolumn{2}{|c|}{ pH (1:2.5) } & \multirow{2}{*}{$\begin{array}{c}\mathrm{EC} \\
\left(\mathrm{dSm}^{-1}\right)\end{array}$} & OC & \multirow{2}{*}{$\frac{\text { TN }}{-1}$} & \multirow{2}{*}{$\begin{array}{c}\mathbf{A P} \\
\mathrm{mg} \mathrm{kg}_{1}^{-}\end{array}$} & $\mathrm{Ca}$ & Mg & K & $\mathrm{Na}$ & CEC & \multirow{2}{*}{$\begin{array}{c}\text { BS } \\
(\%)\end{array}$} \\
\hline & & Water & $\mathrm{CaCl}_{2}$ & & $\mathrm{~g} \mathrm{~kg}^{-1}$ & & & \multicolumn{5}{|c|}{$\mathrm{cmol} \mathrm{kg}^{-1}$} & \\
\hline \multicolumn{14}{|c|}{ Malikawa Series- Pedon Orc P1 (Aquic Ustipsamments/Rubic Arenosols (Eutric) } \\
\hline Ap & $0-8$ & 7.34 & 6.84 & 0.01 & 10.80 & 0.99 & 34.31 & 14.10 & 1.43 & 0.13 & 2.38 & 18.40 & 98.04 \\
\hline $\mathrm{Bw}$ & $8-12$ & 7.59 & 6.96 & 0.01 & 4.40 & 0.99 & 44.88 & 10.80 & 1.03 & 0.07 & 2.08 & 14.30 & 97.76 \\
\hline $\mathrm{AB}$ & $12-70$ & 7.99 & 7.19 & 0.01 & 7.00 & 2.11 & 16.59 & 13.20 & 1.65 & 0.12 & 1.73 & 16.90 & 98.82 \\
\hline- & $>70$ & \multicolumn{12}{|c|}{ Water table } \\
\hline \multicolumn{14}{|c|}{ Malikawa Series- Pedon Orc P2 (Aquic Ustipsamments/Rubic Arenosols (Eutric) } \\
\hline Ap & $0-10$ & 7.23 & 7.52 & 0.01 & 2.60 & 0.94 & 33.19 & 9.92 & 1.82 & 0.10 & 0.70 & 12.70 & 98.74 \\
\hline Bw1 & $10-41$ & 7.17 & 6.48 & 0.01 & 1.20 & 0.60 & 23.76 & 6.58 & 0.85 & 0.07 & 0.86 & 8.60 & 97.21 \\
\hline $\mathrm{AB}$ & $41-63$ & 6.65 & 5.10 & 0.01 & 1.20 & 0.49 & 26.02 & 6.34 & 1.03 & 0.07 & 1.02 & 8.80 & 96.14 \\
\hline Bw2 & 63-114 & 7.58 & 6.53 & 0.01 & 1.60 & 0.35 & 10.94 & 5.44 & 0.62 & 0.03 & 0.98 & 7.40 & 95.54 \\
\hline- & $>114$ & \multicolumn{12}{|c|}{ Water table } \\
\hline \multicolumn{2}{|c|}{ Mean } & 7.36 & - & 0.01 & 4.11 & 0.92 & 27.10 & 9.48 & 1.20 & 0.08 & 1.39 & 12.44 & 97.46 \\
\hline \multicolumn{2}{|c|}{ SE } & 0.17 & - & 0.02 & 0.88 & 0.30 & 2.94 & 1.93 & 0.12 & 0.03 & 0.14 & 2.00 & 0.87 \\
\hline
\end{tabular}

$\mathrm{SE}=$ standard error, $\mathrm{pH}=$ soil reaction, $\mathrm{EC}=$ electrical conductivity, $\mathrm{OC}=$ organic carbon, $\mathrm{TN}=$ total nitrogen, $\mathrm{AP}=$ available phosphorus, $\mathrm{CaCl}_{2}=$ calcium chloride, $\mathrm{Ca}=$ calcium, $\mathrm{Mg}=$ magnesium, $\mathrm{K}=$ potassium, $\mathrm{Na}=$ sodium, $\mathrm{CEC}=$ cation exchange capacity, $\mathrm{Mg}=$ magnesium, $\mathrm{BS}=$ base saturation

Table-4: Correlation (r) Analysis of the Soils of Malikawa Series Pedons Orc P1 and P2

\begin{tabular}{|c|c|c|c|c|c|c|c|c|c|c|c|c|c|c|}
\hline & Sand & Silt & Clay & BD & Por & pH & OC & TN & $\mathbf{A P}$ & $\mathbf{C a}$ & Mg & $\mathbf{K}$ & $\mathrm{Na}$ & CEC \\
\hline Silt & $\begin{array}{c}- \\
0.971 * *\end{array}$ & & & & & & & & & & & & & \\
\hline Clay & $\begin{array}{c}- \\
0.995^{* *}\end{array}$ & $0.951 * *$ & & & & & & & & & & & & \\
\hline BD & 0.207 & -0.229 & -0.299 & & & & & & & & & & & \\
\hline Por & -0.056 & 0.089 & 0.115 & $\begin{array}{c}- \\
0.988^{* * *}\end{array}$ & & & & & & & & & & \\
\hline $\mathrm{pH}$ & -0.587 & 0.508 & 0.561 & 0.054 & -0.156 & & & & & & & & & \\
\hline OC & $-0.828^{*}$ & $0.838^{*}$ & 0.797 & -0.103 & -0.018 & $0.795^{*}$ & & & & & & & & \\
\hline TN & $-0.826^{*}$ & $0.893^{*}$ & 0.777 & -0.074 & -0.042 & $0.686^{*}$ & $0.952 *$ & & & & & & & \\
\hline $\mathbf{A P}$ & -0.360 & 0.310 & 0.441 & -0.807 & 0.766 & -0.195 & 0.079 & -0.012 & & & & & & \\
\hline $\mathbf{C a}$ & $\begin{array}{c}- \\
0.949^{* *}\end{array}$ & $0.963^{* * *}$ & $0.934 * *$ & -0.289 & 0.153 & $0.643 * *$ & $0.938^{* * *}$ & $0.930^{* * *}$ & 0.324 & & & & & \\
\hline Mg & 0.860 & $0.906^{* * *}$ & $0.835^{* * *}$ & -0.049 & -0.077 & 0.209 & $0.567^{* * *}$ & $0.703^{* * *}$ & 0.230 & 0.762 & & & & \\
\hline K & $\begin{array}{c}- \\
0.801^{* *}\end{array}$ & 0.918 & $0.761^{* * *}$ & -0.208 & 0.103 & $0.261 * *$ & 0.688 & $0.848^{* *}$ & 0.189 & 0.831 & 0.911 & & & \\
\hline $\mathrm{Na}$ & $\begin{array}{c}- \\
0.470^{* *}\end{array}$ & $0.473^{* * *}$ & 0.487 & -0.379 & 0.317 & $0.592 * *$ & $0.761 * *$ & 0.570 & 0.367 & 0.655 & 0.048 & $0.228 * *$ & & \\
\hline CEC & -0.940 & 0.952 & 0.927 & -0.296 & $0.162^{* *}$ & 0.631 & 0.941 & 0.922 & 0.347 & $\begin{array}{l}0.998 \\
\end{array}$ & $0.741^{* * *}$ & 0.815 & 0.690 & \\
\hline PBS & -0.910 & 0.949 & 0.899 & -0.416 & 0.286 & 0.430 & 0.702 & 0.795 & 0.388 & 0.887 & 0.878 & 0.904 & 0.301 & 0.864 \\
\hline
\end{tabular}

$\mathrm{BD}=$ bulk density, $\mathrm{Por}=$ porosity, $\mathrm{OC}=$ organic carbon, $\mathrm{TN}=$ total nitrogen, $\mathrm{AP}=$ available phosphorus, $\mathrm{Ca}=$ calcium, $\mathrm{Mg}=\mathrm{magnesium}$, $\mathrm{K}=$ potassium, $\mathrm{Na}=$ sodium, $\mathrm{CEC}=$ cation exchange capacity, $\mathrm{PBS}=$ percent base saturation 


\section{REFERENCES}

1. Bajracharya, R. M., Sitaula, B. K., Shrestha, B. M., Awasthi, K. D., Balla, M. K., \& Singh, B. R. (2004). Soil organic carbon status and dynamics in the central Nepal Middle Mountains. Journal of Institute of Forestry, 12: 2844.

2. Jobbágy, E. G. and Jackson, R. B. (2001). The distribution of soil nutrients with depth: Global patterns and the imprint of plants. Biogeochemistry, 53(1): 51-77.

3. Hannah, R., \& Max, R. (2020). "Land Use". Published online at OurWorldInData.org. Retrieved from: 'https://ourworldindata.org/land-use' [Online Resource]

4. Daniel, K. W., Milu, M., Joseph, M., \& Thomas, J. (2019). The effect of land use change on soil fertility parameters in densely populated areas of Kenya. Geoderma. 343: 254-262.

5. Rientjes, T., Haile, A., Kebede, E., Mannaerts, C. Habib, E., \& Steenhuis, T. (2011). Changes in land cover, rainfall and stream flow in Upper Gilgel Abbay catchment, Blue Nile basin-Ethiopia. Hydrol. Earth Syst. Sci., 15(6): 19791989.

6. Jacob, M., Frankl, A., Beeckman, H., Mesfin, G., Hendrick, M., Guyassa, E., Nyssen, J. (2015). North Ethiopian afro-alpine tree line dynamics and forest-cover change since the early 20th century. Land Degrad. Dev., 26(7): 654664.

7. Haregeweyn, N., Tsunekawa, A., Nyssen, J., Poesen, J., Tsubo, M., Tsegaye Meshesha, D., Schütt, B., Adgo, E., Tegegne, F. (2015). Soil erosion and conservation in Ethiopia: a review. Prog. Phys. Geogr., 39(6): $750-774$.

8. Asadu, C.L.A., Ezeaku, P.I., \& Nnagi, G.U. (2004). Land use and soil management situation in Nigeria: An analytical review of changes. Outlook on Agriculture. SAGE Publications.

9. Don, A., \& Schumacher, F. A. (2011). Impact of tropical land-use change on soil organic carbon stocks: metaanalysis. Glob. Chang. Biol., 17: 1658-1670.

10. Tolessa, T., Dechassa, C., Simane, B., Alamerew, B., Kidane, M. (2019). Land use/land cover dynamics in response to various driving forces in Didessa sub-basin, Ethiopia. Geojournal:

11. Akamigbo, F. O., \& Asadu, C. I. (2001). The Influence of Parent Materials on the Soils of Southern Nigeria. East Afr. Agric \& Forest: 81-91.

12. Alexandra, M., Charles, R., Jeangros, D., \& Sinaj, S. (2013). Effect of Organic Fertilizers and Reduce-Tillage on Soil Properties, Crop Nitrogen Response and Crop Yield: Results of a 12-year experiment in Changins, Switzerland. Soil and Tillage Research, 126: 11-18.

13. Sharma, Y. K., Sharma, A., \& Sharma, K. S. (2013). An Appraisal of Physico-chemical Characteristics and Soil Fertility Status of Forest and Rice Land Use Systems in Mokokchung District of Nagaland. Journal of Indian Society of Soil Science, 1(2): 38-43.

14. Anđelković, M., Baralić, I., Đorđević, B., Stevuljević, J. K., Radivojević, N., Dikić, N., ... \& Stojković, M. (2015). Hematological and biochemical parameters in elite soccer players during a competitive half season. Journal of medical biochemistry, 34(4), 460-466.

15. Khan, A., Jan, M. T., Marwat, K. B., \& Arif, M. (2009). Organic and Inorganic nitrogen treatment effects on plant and yield attributes of maize in different tillage systems. Pakistan Journal of Botany, 41(1): 99-108.

16. Heluf, G., \& Wakene, N. (2010). Impact of land use and management practices on chemical properties of some soils of Bako areas, Western Ethiopia. Ethiopian Journal of Natural Resources, 8(2): 177-197.

17. Doran, J.W., \& Parkin, T.B. (1994). Defining and assessing soil quality. In: J.W. Joran, D.C. Coleman, D.F. Bezdicek and B.A. Stewart (Eds), Defining Soil Quality for Sustainable Environment, SSSA Special Publ. No. 35, Madison, Wisconsin, USA, 1-21.

18. Sanchez, P. A., Shepherd, K. D., Soule, M. J., Place, F. M., Buresh, R. J., Izac, A. M. N., ... \& Woomer, P. L. (1997). Soil fertility replenishment in Africa: an investment in natural resource capital. Replenishing soil fertility in Africa, 51, 1-46.

19. Maddonni, G. A., Urricariet, S., Ghersa, C. M., \& Lavado, R. S. (1999). Assessing soil quality in the Rolling Pampa, using soil properties and maize characteristics. Agronomy Journal, 91(2), 280-287.

20. Ahukaemere, C. M., \& Akpan, E. L. (2012). Fertility Status and Characterization of Paddy Soils of Amasiri In Ebonyi State, Southeastern Nigeria. PAT, 8(2), 159-168.

21. NMA. (2011). Nigerian Meteorological Agency. Sultan Abubakar International Airport Sokoto, Nigeria.

22. Sombroek, W. G., \& Zonneveld, I. S. (1971). Ancient dune fields and fluviatile deposits in the Rima-Sokoto river basin (NW Nigeria): geomorphologic phenomena in relation to Quaternary changes in climate at the southern edge of the Sahara (No. 5). Stichting voor Bodemkartering Wageningen.

23. Jahn, R., Blume, H. P., Asio, V. B., Spaargaren, O., \& Schad, P. (2006). Guidelines for soil description. FAO.

24. ISRIC/FAO. (2002). Procedures for soil analysis, sixth edition. In: L.P. Van Reeuwijik (ed.), International Soil Reference and Information Center/FAO, 119.

25. Blake, G. R., \& Hartge, K. H. (1986). Bulk density. Methods of soil analysis: Part 1 Physical and mineralogical methods, 5, 363-375.

26. Black, C.A. (1965). Methods of Soil and Plant Analyses. Agron. No.9, Part 2 Amer. Soc. Madison. 
27. Thomas, G. W. (1996). Soil pH and Soil Acidity. In: D. L. Sparks (ed.) Methods of Soil Analysis Part 3 - Chemical Methods. SSSA Book Series 5, Madison, Wisconsin, USA. 475 - 490.

28. Nelson, D. W., \& Sommers, L. E. (1996). Total carbon, organic carbon, and organic matter. Methods of soil analysis: Part 3 Chemical methods, 5, 961-1010.

29. Bremner, J. M. (1996). Nitrogen- total. Methods of Soil Analysis: Part 3 Chemical Methods, 5, 1085-1121.

30. Kuo, S. (1996). Phosphorus. In: D. L. Sparks (ed.), Methods of Soil Analysis, Part 3 - Chemical Methods. SSSA Book Series 5, Madison, $869-920$ pp.

31. Masbni, J., \& J. Strang. (2007). Orchard site rating sheet. HortFact-3005. UK Cooperative Extension Service, University of Kentucky- College of Agriculture, Horticulture Department. Issued: April, 2007; Revised. 3.

32. Anonymous. (2017). what is a water table? Accessed on Saturday 27/05/2017 via google search machine around 08:40 am. The search question was "importance of water table pdf'. Document type: Microsoft word pdf. (C) American Ground Water Trust. www.agwt.com

33. Salazar, O. (2003). Agroforestry combined with water harvesting in the central zone of Chile: soil properties and biomass production. Sveriges lantbruksuniv..

34. Yamoah, C. F., Agboola, A. A., Wilson, G. F., \& Mulongoy, K. (1986). Soil properties as affected by the use of leguminous shrubs for alley cropping with maize. Agriculture, ecosystems \& environment, 18(2), 167-177.

35. Rao, M. R., Nair, P. K. R., \& Ong, C. K. (1997). Biophysical interactions in tropical agroforestry systems. Agroforestry systems, 38(1-3), 3-50.

36. Buol, S. W., Southard, R. J., Graham, R. C., \& McDaniel, P. A. (2011). Soil genesis and classification. John Wiley $\&$ Sons.

37. Bally, I.S.E. (2006). Mangifera indica (Mango). Species profiles for pacific island agroforestry. www.traditionaltree.org

38. Akinola, J.O. (1975). A preliminary assessment of forage legumes grown under irrigation for out-of-season dry matter and crude protein production. Samaru Agricultural Newsletter, 17(2): 62-67.

39. Skujins, J. (1991). Semi-arid land and deserts: Soil Resources Reclamation. New York, USA, Mercel Dekker Inc, 668.

40. Murthy, A.S.P. (1988). Distribution, properties and management of Vertisols in India. Advances in Soil Science, 8: 151-214.

41. Bopathi, H.K., \& Sharma, K.N. (2006). Phosphorus adsorption and desorption characteristics of some soils as affected by clay and available phosphorus content. Journal of the Indian Society of Soil Science, 54(1): 111-114.

42. Excel, (2016). Microsoft office. Version 2016.

43. Ogeh, J.S., \& Ukodo, E. (2012). Profile distribution of physical and chemical properties of soils of toposequence in Benin, Rainforest of Nigeria. Nigerian Journal of Basic and Applied Science, 20(1): 68-72. 